\title{
VARIOUS SPECIES OF GLOEOSPORIUM IN STORED APPLES IN FINLAND
}

\author{
PENTTI TALVIA
}

Agricultural Research Centre, Department of Plant Pathology, Tikkurila

Received May 19, 1960

In storage trials on apples carried out in the years $1952-1955$ by the Department of Plant Pathology, the most important cause of losses in the stored fruit was apple rot caused by the fungus Gloeosporium (8). JamalaInEN determined the causal agent to be Gloeosporium album Osterw. and mentioned that possibly other species of Gloeosporium were also involved in causing the disease.

Since 1954 the Department of Plant Pathology has continued its trials on stored apples in order to determine the various species of Gloeosporium found in this fruit during storage. Apple growers throughout the country were requested to send diseased apples to the Department for investigation. In the storage period 1954/55 determinations were made on 13 apple varieties from 9 different locations in southern Finland. In the period 1956/57 ten apple varieties from five localities were included in the trials. In the autumn 1957 the Department received for investigation 9 varieties of apples infected with rot from 11 growers throughout the country. In addition, determinations were made during the trial period 1957/58 on the Gloeosporium species occurring in apples in the Department's own storage trials. The experimental material in the years $1954-58$ included a total of 20 apple varieties from 17 different localities in Finland.

The trial material was stored in a cellar where the temperature averaged $4^{\circ} \mathrm{C}$. and the relative humidity approximately $92 \%$. Determinations of the fungus species in the diseased apples were made during the storage period on the basis of the form and shape of the acervuli as well as on the size and form of the conidia.

Table 1 shows results of determinations made in the period $1954-58$ on the occurrence of Gloeosporium species in apples from various localities in Finland. $G$. perennans Zeller \& Childs was found in apples from all of the localities and appears to be the principal species in many areas. The second most widespread species was $G$. album, which, together with $G$. perennans, is the cause of extensive damage to stored apples in Finland. The third species, G. fructigenum Berk., is much less important as a cause of apple rot in this country. 
Table 1. Occurrence of Gloeosporium species in diseased apple material from different regions of Finland, 1954-58. Species determinations made on the basis of acervuli and conidial shape and size.

Plant geographical province and locality

$\begin{array}{cc}\begin{array}{c}\text { No. of } \\ \text { apple } \\ \text { varieties }\end{array} & \begin{array}{c}\text { No. of } \\ \text { examined } \\ \text { diseased } \\ \text { apples }\end{array}\end{array}$

\begin{tabular}{ccc}
\multicolumn{3}{c}{ Gloesporium } \\
G. album & G. fructi- & G. peren- \\
& genum & nans \\
$\%$ & $\%$ & $\%$ \\
\hline
\end{tabular}

Regio aboensis

Lohja $\quad \ldots \ldots \ldots \ldots \ldots \ldots \ldots$
Nummi $\quad \ldots \ldots \ldots \ldots \ldots \ldots \ldots$
Piikkiö $\quad \ldots \ldots \ldots \ldots \ldots \ldots \ldots$
Särkisalo $\quad \ldots \ldots \ldots \ldots \ldots \ldots \ldots$
Tenhola $\quad \ldots \ldots \ldots \ldots \ldots \ldots$

Nylandia

\begin{tabular}{|c|c|}
\hline Espoo $\ldots$ & $\ldots \ldots \ldots \ldots \ldots \ldots$ \\
\hline Helsinki & $\ldots \ldots$ \\
\hline Tikkurila & a \\
\hline Hyvinkää . & $\ldots \ldots$ \\
\hline Järvenpää & $\ldots \ldots \ldots \ldots$ \\
\hline
\end{tabular}

Satakunta

Karkku $\ldots \ldots \ldots \ldots \ldots \ldots \quad 1$

Köyliö ............ 1

Tavastia australis

Kangasala $\ldots \ldots \ldots \ldots \ldots \ldots \quad 1$

Pälkäne $\quad \ldots \ldots \ldots \ldots \ldots \ldots . \ldots \ldots$

Tyrväntö ........... 3

Vanaja .............. 2

Savonia australis

Lauritsala

1

$\begin{array}{rrrr}376 & 19 & 3 & 7 \\ 7 & 29 & 0 & 7 \\ 177 & 38 & 4 & 5 \\ 19 & 0 & 0 & 100 \\ 2054 & 43 & 2 & 5\end{array}$

2

\begin{tabular}{|c|c|}
\hline 64 & 56 \\
\hline 18 & 39 \\
\hline 1900 & 78 \\
\hline 97 & 17 \\
\hline 98 & 28 \\
\hline
\end{tabular}

$\begin{array}{llll}26 & 54 & 0 & 46 \\ 61 & 34 & 3 & 63\end{array}$

$\begin{array}{rrrr}40 & 0 & 0 & 100 \\ 48 & 6 & 0 & 91 \\ 341 & 9 & 0 & 91 \\ 11 & 18 & 0 & 82 \\ 45 & 13 & 0 & 87\end{array}$

Since the apple samples from several of the localities were limited these results do not give a completely accurate picture of the extent of Gloeosporium fungi in Finland.

Investigations made at the Lindö Estate at Tenhola in southwestern Finland upon apples of the Wealthy variety show that the relative proportions of the Gloeosporium species can vary considerably in the same apple variety, even in closely located orchards. For example, in one orchard containing trees older than ten years, determinations on 1455 diseased apples showed that $G$. perennans was the causal agent in $72 \%$ and $G$. album in $26 \%$ of the infected fruit. In a second orchard located two kilometers distant and containing trees younger than ten years of age, the proportions of the two species was almost reversed; out of 599 infected apples $G$. album was responsible for $84 \%$ of the diseased fruit and $G$. perennans for only $15 \%$.

Moisture conditions during the growing season appear to have an effect on the relative occurrence of Gloeosporium species in stored apples (10). Determinations of the fungus species infecting Melba-variety apples grown at the Department of Plant Pathology orchard were made in the years 1956 and 1957. These two years differed considerably from one another in terms of precipitation during the growing season. In the year 1956 May, July and especially September (only 7 days of rainfall) were 
dryer than normal whereas August was a rainy month. In 1957, on the other hand, precipitation during the early part of the summer was normal whereas August and September were characterized by abundant rainfall (in September there were 22 days of rainfall). In the former year 1956, investigations on 650 Melba apples showed $36.4 \%$ to be diseased, of which $97.5 \%$ were infected by $G$. album and $2.5 \%$ by $G$. perennans. In 1957 a total of 1680 apples were investigated; of these $51.7 \%$ were infected, and the relative amounts of the Gloeosporium species were $81.2 \%$ G. album and the remainder $G$. perennans.

\section{Gloeosporium perennans Zeller \& Childs}

G. perennans is known as an important causal agent of apple rot, especially in fruit preserved in cold storage $(5,6,12)$. In addition to infecting the fruit, this fungus also forms small cankers or areas of bark blight in the branches of the tree. In such infected areas watery, greyish-coloured, stroma-like acervuli are formed which, during warm temperature conditions, produce abundant conidia. The conidia then infect the fruit via the stomata. Later during the period of storage, round decaying spots appear on the apple. These spots contain acervuli which develop first under the epidermis and after break through to the surface. Numerous conidia are formed in these acervuli at low temperatures $\left(2^{\circ}-4^{\circ} \mathrm{C}\right.$.).

In Sweden (11) and in Denmark (15) G. perennans, together with G. album, is the most important cause of apple rot. In Norway (16) the species has been known since 1950 but is of small significance in that country. In England (6), Holland (12), New Zealand (5), and in North America (1) G. perennans is an important causal agent of rot in stored apples.

Gloeosporium perennans cannot be distinguished morphologically from $G$. malicorticis Cordl. (3). The ascospore stage of $G$. perennans is known by the names Pezicula malicorticis (Jacks.) Nannf. and Neofabrea malicorticis (Cord.) Jacks. It has been found in North America, in Holland and in England (4, 7, 9), but only in winter cankers of Pyrus species.

The infection caused by $G$. perennans appears generally on the surface of the apple but sometimes it occurs also on the stipe. The infection spots are brown in colour, and are usually surrounded by a darker border. The acervuli are forced through the epidermis to the surface where they expand and become filled with a grey mass of conidia. In apples stored in moist conditions the infection spots with their acervuli are often watery in appearance. The infection spreads rapidly to the interior of the apple and the entire fruit becomes shrivelled.

The conidia are one-celled, elongate, and are straight or slightly curved (Fig. la). A light-coloured vacuole-like area is often visible in the center of the conidium. The length of the conidium varies on the average, from 11.6 to $17.6 \mu(5.8-25.3 \mu)$. The average value of conidium length as determined by 480 measurements on conidia from 12 apple varieties was $14.96 \mu$.

The width of the conidia varied from 2.8 to $4.9 \mu(1.0-5.9 \mu)$ with an average value of $3.95 \mu$. According to OORT (12) the size of the conidia of G. perennans 


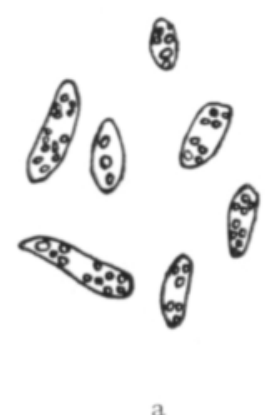

a
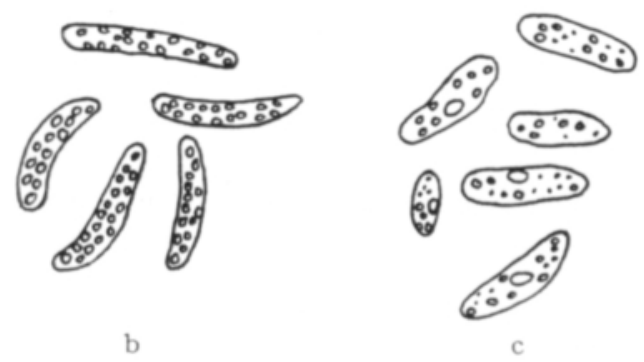

c

Fig. 1. a) G. perennans, b) G. album, c) G. fructigenum. $\times 760$.

varies with the ranges $7.2-20.0 \mu \times 3.0-6.4 \mu$ (average $13.6 \times 4.0 \mu$ ). Microconidia are also generally produced by this fungus.

Conidia isolated from infected apples have been cultured on $5 \%$ oat-agar and on $3 \%$ glucose-agar. The mycelium is lightcoloured and abundant conidia are formed.

\section{Gloeosporium album Osterw.}

G. album, which has many synonyms, is, together with $G$. perennans, an important cause of apple rot. It is responsible for great losses of fruit in cold storage in many countries, such as Sweden, Norway, Holland, England, Switzerland and New Zealand $(5,11,12,13,16,18)$. Conidia are formed on the dead branches of the fruit tree and subsequently infect the apples principally via the stomata. At the site of infection brown-coloured spots surrounded by a dark border appear. These spots are often lighter in colour than those of G. perennans and are found usually on the surface of the apple but sometimes also at the base of the stipe. Round, light-coloured clusters of conidiophores develop in the infection spots and often assume the form of a ring in the surface of the spot. Under moist conditions white, ray-like aerial hyphae grow out from the infected area. According to Guthrie (7) the perfect stage of $G$. album is Pezicula alba Guthrie.

The conidia of G. album are one-celled, cylindrical and usually curved (Fig. 1 b). Sometimes they are discharged in white, ribbon-like masses. The length of the conidia was found to vary from 17.9 to $24.9 \mu(13.8-28.0 \mu)$ with an average figure of $20.75 \mu$ obtained from measurements of 440 conidia on 14 apple varieties. Their width ranged from 2.3 to $3.8 \mu(2.1-4.5 \mu)$ with an average of $2.86 \mu$. According to OSTERWALDER (13) the size of Gloeosporium album conidia are on the average $24 \times$ $3 \mu$ and according to OORT (12) $22.5(16.5-29.0) \times 3.7 \mu(3.2-4.0)$.

When cultured on oat-agar and on glucose-agar, G. album grows very slowly. It forms a white-coloured mycelium but produces very few conidia. 
G. jructigenum Berk. is the imperfect stage of Glomerella cingulata (Ston.) Spauld. \& Schr. and has many synonyms (cf. 2). The imperfect stage of this fungus has been isolated from a wide number of various plants. In 1935 RaINIo (14) determined the fungus as the causal agent of anthracnose in an agave plant growing in a greenhouse in Finland. G. fructigenum is widely distributed in both the tropics and in temperate regions. It occurs in Scandinavia and other European countries as well as in North America, but it is not important as a cause of apple rot $(1,11,12$, $13,15,16,18)$. It is, however, believed to be responsible for fruit rot in cherries, olives and in certain tropical fruit (3).

G. fructigenum infects apples usually at sites of injury, but it is also capable of penetrating through the epidermis. Brown-coloured depressed spots are formed at the site of infection and small, dark acervuli gradually develop in these spots. Under pressure from the expanding conidial mass the epidermis breaks and the conidia are released to the exterior. In moist conditions masses of conidia accumulate as reddishcoloured globules on the surface of the acervuli. The disease spreads slowly within the apple, and many weeks may pass before the apple is completely decayed.

The conidia are one-celled, colorless, cylindrical, and straight or slightly curved (Fig. 1 c). The length of the conidia ranges from 15.2 to $18.0 \mu$ and averages $16.1 \mu$

Table 2. Occurrence of Gloeosporium species in apple varieties cultivated in Finland. Species determinations made on apple rot material received in 1954-58 on the basis of acervuli and conidial shape and size.

\begin{tabular}{|c|c|c|c|c|c|}
\hline \multirow{2}{*}{ Apple variety } & \multirow{2}{*}{$\begin{array}{l}\text { Areas of } \\
\text { cultivation }\end{array}$} & \multirow{2}{*}{$\begin{array}{l}\text { No. of } \\
\text { examined } \\
\text { diseased } \\
\text { apples }\end{array}$} & \multicolumn{3}{|c|}{ Gloeosporium species } \\
\hline & & & $\begin{array}{c}\text { G. album } \\
\%\end{array}$ & $\begin{array}{c}\text { G. fructi- } \\
\text { genum } \\
\%\end{array}$ & $\begin{array}{c}\text { G. peren- } \\
\text { nans } \\
\%\end{array}$ \\
\hline Antonovka...$\ldots \ldots \ldots \ldots \ldots$ & 6 & 567 & 17 & 4 & 79 \\
\hline Atlas $\quad \ldots \ldots \ldots \ldots \ldots \ldots \ldots$ & 1 & 18 & 29 & 5 & 66 \\
\hline Cellini $\ldots \ldots \ldots \ldots \ldots \ldots \ldots \ldots$ & 2 & 15 & 67 & 0 & 33 \\
\hline Harlamovski $\ldots \ldots \ldots \ldots \ldots \ldots$ & 1 & 53 & 51 & 0 & 49 \\
\hline Harmaa Gylling (= grey Gylling) & 1 & 18 & 39 & 0 & 61 \\
\hline Joyce $\ldots \ldots \ldots \ldots \ldots \ldots \ldots \ldots$ & 1 & 99 & 39 & 0 & 61 \\
\hline Kaikuvuori $\quad \ldots \ldots \ldots \ldots \ldots \ldots$ & 2 & 14 & 79 & 0 & 21 \\
\hline Kelt. kaneli (= yellow canel) $\ldots$ & 1 & 19 & 0 & 0 & 100 \\
\hline Kirkniemi $\ldots \ldots \ldots \ldots \ldots \ldots \ldots$ & 1 & 54 & 26 & 6 & 68 \\
\hline Lepaan liereä (= lepaa round) & 1 & 156 & 1 & 0 & 99 \\
\hline Linda $\ldots \ldots \ldots \ldots \ldots \ldots \ldots \ldots \ldots$ & 2 & 42 & 64 & 0 & 36 \\
\hline Lobo $\ldots \ldots \ldots \ldots \ldots \ldots \ldots \ldots$ & 5 & 183 & 5 & 0 & 95 \\
\hline Melba $\ldots \ldots \ldots \ldots \ldots \ldots \ldots$ & 1 & 1118 & 84 & 0 & 16 \\
\hline Oranie $\ldots \ldots \ldots \ldots \ldots \ldots \ldots \ldots$ & 1 & 10 & 10 & 0 & 90 \\
\hline Safran-Pohjola $\ldots \ldots \ldots \ldots \ldots$ & 1 & 29 & 76 & 0 & 24 \\
\hline Sariola $\quad \ldots \ldots \ldots \ldots \ldots \ldots \ldots$ & 3 & 166 & 20 & 1 & 79 \\
\hline Signe Tillish $\ldots \ldots \ldots \ldots \ldots \ldots$ & 1 & 76 & 20 & 0 & 80 \\
\hline Slavjanka $\ldots \ldots \ldots \ldots \ldots \ldots$ & 1 & 35 & 40 & 0 & 60 \\
\hline Wealthy $\ldots \ldots \ldots \ldots \ldots \ldots \ldots$ & 5 & 2568 & 52 & 2 & 46 \\
\hline Åkerö $\ldots \ldots \ldots \ldots \ldots \ldots \ldots \ldots \ldots$ & 5 & 142 & 48 & 0 & 52 \\
\hline
\end{tabular}


on the basis of 100 measurements from five apple varieties; their width is 4.3 to $5.4 \mu$ with an average of $4.9 \mu$. According to ARX (2) the size of the conidia of $G$. fructigenum averages $12-22 \times 4-6 \mu$. On oat-agar and glucose-agar the fungus forms a grey mycelium and produces conidia.

\section{Gloeosporium species in the material studied}

It has been determined in previous investigations in Finland that there are considerable differences in resistance to Gloeosporium rot among different apple varieties (8). Table 2 shows the occurrence of the various species of Gloeosporium in different apple varieties. None of the apple varieties were found to be completely

Table 3. Occurrence of Gloeosporium species at various dates in stored apples at Tikkurila and at Tenhola, 1956/57 and 1957/58.

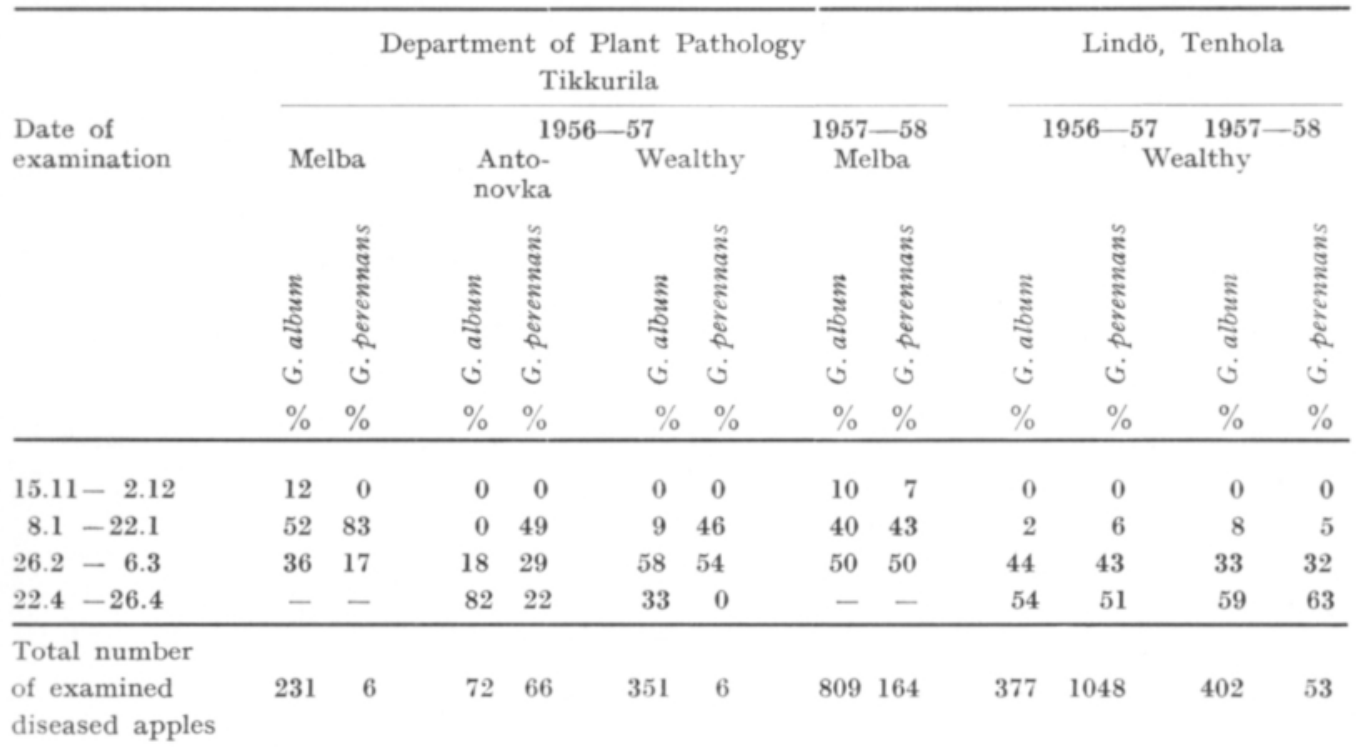

resistant to these fungi (cf. 5, 11). In the varieties Antonovka, Lepaa round and Sariola $G$. perennans was found to occur more than $G$. album, whereas in Melba G. album was the more common species. In Wealthy and Åkerö apples both species of Gloeosporium occurred in approximately equal amounts.

In Table 3 are presented observations on the occurrence of Gloeosporium species at various dates during the storage seasons $1956 / 57$ and $1957 / 58$. These observations were made at Tikkurila on three apple varieties and at Lindö on the one variety Wealthy. Apple rot caused by the two species of Gloeosporium appeared in the apples at approximately the same time, during the month of January. The date of first appearance of apple rot varied in the two years, occurring somewhat earlier in the 
storage period $1957 / 58$. This earlier appearance of apple rot was correlated with the earlier ripening of the apples, which was caused by the weather conditions during the growing season.

Control of Gloeosporium rot in stored apples was attempted in the years 1956 and 1957 by means of fungicidal sprays on the apples during the growing season. From two to nine sprayings were carried out between the dates May 29 and September 15 upon the two apple varieties Melba and Wealthy which are susceptible to Gloeosporium rot. Spraying with captane, thiram or thiram + carbamate + asam significantly reduced the occurrence of apple rot during the following storage period (17). The fungicides used appear to have had a more effective control on G. perennans than on $G$. album. In general, the relative proportion of $G$. perennans as a cause of apple rot decreased more than G. album when the number of treatments was increased.

Studies have also been carried out on the effect of carbon dioxide gas during storage upon the occurrence and relative proportions of Gloeosporium species. It was found that carbon dioxide treatment $(4.5-7.0 \%)$ reduced the amount of apple rot in practically all of the eight varieties of apples which were included in the trials. In comparison to normal storage conditions, the relative proportion of G. album as a cause of apple rot was decreased $10 \%$ by the $\mathrm{CO}_{2}$ treatment, with the proportion of $G$. perennans correspondingly increasing.

\section{$S u m m a r y$}

Gloeosporium perennans Zeller \& Childs and G. album Osterw. were determined as the most important causal agents of apple rot in storage among 20 apple varieties from 17 localities in Finland. G. fructigenum Berk. was relatively insignificant in causing the disease. Infection spots of both $G$. perennans and G. album began to appear in the fruit at approximately the same time during January.

All of the apple varieties investigated were found to be susceptible to Gloeosporium rot, although there were distinct differences in the susceptibility of certain varieties to one or another of the two species.

The occurrence of the Gloeosporium species varied considerably in the same apple variety between different orchards. External factors such as dry weather in the late summer, fungicidal sprays, and carbon dioxide during storage were found to decrease the occurrence of Gloeosporium rot in stored apples as well as to cause changes in the relative proportions of the two species $G$. perennans and G. album.

\section{REFERENCES}

(1) Anderson, H. W. 1956. Diseases of Fruit Crops. York, 501 p.

(2) ARx, J. A. von 1957. Die Arten der Gattung Colletotrichum Cda. Phytopath. Z. 29: 413-468.

(3) - 1958. Die Gloeosporien des Kernobstes. Ibid. 33: 108-114.

(4) Bolay, A. 1956. Observation en Hollande de la forme parfaite du champignon Gloeosporium perennans Zeller et Childs. Tijdschr. Plantenziekten 62: 322-324.

(5) Ввоок, P. J. 1957. Ripe spot of Apples in New Zealand. N. Z. J. Sci. Tech., Sect. A, 38, 7: 735741. (Ref. Rev. Appl. Myc. 37: 88) 
(6) EdNey, K. L. 1956. The rotting of apples by Gloeosporium perennans Zeller \& Childs. Ann. appl. Biol. 44: $113-128$.

(7) Guthrie, E. J. 1959.The occurrence of Pezicula alba sp. now. and $P$. malicorticis, the perfect states of Gloeposporium album and G. perennans, in England. Trans. Brit mycol. Soc. 42: 502506.

(8) Jamalainen, E. A. 1953. Suomessa viljeltyjen omenalajikkeiden säilyvyydestä varastossa. Summary: On storage qualites of varietis of apples grown in Finland. J. Agric. Sci. Finl. 25: $136-146$.

(9) Kienholz, J. R. 1939. Comparative study of the apple anthracnose and perennial canker fungi. J. agric. Res. 59: 635. (Ref. Rev. Appl. Myc. 19: 226)

(10) Moore, M. H. \& Edney, K. L. 1959. The timing of spray treatments for the control of storage rot of apple caused by Gloeosporium spp. Rep. E. Malling Res. Sta. 1958: 106-109.

(11) Olsson, K. 1958. Några försöksresultat med Gloeosporium på äpple. Fruktodlaren 29: $119-120$.

(12) Oort, A. J. P. 1956. Gloeosporium-vruchtrot bij appels. Meded. Landb. hogesch. Gent 31: $507-518$.

(13) Osterwalder, A. 1907. Zur Gloeosporium-Fäule des Kernobstes. Centralblatt f. Bakt. II, 18: $825-827$.

(14) Rarnio, A. J. 1937. Anthraknose der Agaven erzeugt durch Gloeosporium fructigenum Berk. (Colletotrichum agaves Cav. = Gloeosporium agaves Syd.) - Glomerella cingulata (Stonem.) Spauld. \& Scr. Valt. maatal. koetoim. julk. (Publ. Finn. Sta. Agric. Res. Board) 96: 1-20.

(15) Rasmussen, P. M. \& Jepsen, H. M. 1958. Forsøg med bekaempelse af Gloeosporium på aebler. Tidsskr. Pl. avl. 62: 280-291

(16) Schoyen, T. H.\& Jørstad, Ivar 1956. Skadedyr og sykdommer i frukt- og baerhagen. Oslo, 197 p.

(17) TALviA, P. 1957. Syysruiskutukset omenien varastokestävyyden parantajina (The fungicidal sprays on the autumn for the control of storage rot of apples). Finnish. Koetoim. ja käyt. 14: 18.

(18) WiLkinson, E. H. 1954. Fungal rots of apples with special reference to Gloeosporium spp. Ann. Appl. Biol. 41: 354-358.

S E L O T U S:

VARASTOIDÚISSA OMENISSA ESIINTYVISTÄ GLOEOSPORIU $M$-LAJEISTA SUOMESSA

Pentti Talvia

Kasvitautien tutkimuslaitos, Tikkurila

Gloeosporium perennans Zeller \& Childs ja G. album Osterw. todettiin tärkeimmiksi varastolaikun aiheuttajiksi 17:Itä paikkakunnalta saaduista 20 omenalajikkeessa (taulukko 1). G. fructigenumin Berk. merkitys Suomessa viljeltyjen omenien hedelmämädän aiheuttajana on vähäinen. Sekä G. perennansin että G. albumin aiheuttamat mätälaikut alkoivat ilmetä varastoiduissa hedelmissä tammikuun kuluessa samoihin aikoihin (taulukko 3).

Kaikki tutkitut omenalajikkeet olivat alttiit varastolaikun aiheuttajille, joskin eräissä lajikkeissa huomattiin selvempää alttiutta jommalle kummalle tärkeimmälle hedelmämädän aiheuttajalla (taulukko 2).

Gloeosporium-lajien esiintymisrunsaus vaihteli melkoisesti samalla omenalajikkeella läheisissäkin hedelmätarhoissa. Syyskesän kuivuus, fungisiidiruiskutukset ja hiilihapposäilytys vähensivät yleensä varastolaikun esiintymistä sekä aiheuttivat muutoksia tärkeimpien Gloeosporium-lajien esiintymissuhteisiin va rastolaikun aiheuttajina. 